http://jmscr.igmpublication.org/home/

ISSN (e)-2347-176x ISSN (p) 2455-0450

crossref DOI: https://dx.doi.org/10.18535/jmscr/v8i11.03

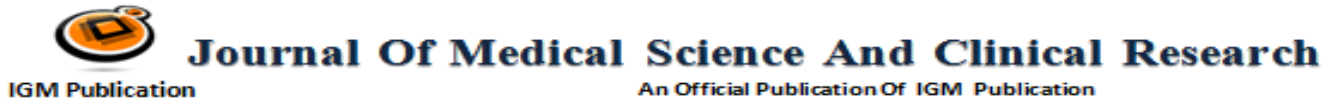

\title{
Current Trend in Acute Intestinal Obstruction Incidence - A Combined Retrospective and Prospective Study
}

Authors

\section{Dr S.Rathan Babu ${ }^{1 *}$, Dr R.Ramesh ${ }^{2}$, Dr K.Ravichandran ${ }^{3}$, Dr R.Jayaraman ${ }^{4}$}

${ }^{1}$ Junior Resident, ${ }^{2}$ Professor and HOD, ${ }^{3}$ Associate Professor, ${ }^{4}$ Assistant Professor, Department of General Surgery, Rajah Muthiah Medical College \& Hospital, Annamalai University, Tamil

Nadu, India

*Corresponding author

Dr S.Rathan Babu

\begin{abstract}
Aims and Objectives: A study was undertaken to identify the common etiology and presentation of acute intestinal obstruction prevailing in our rural vicinity among various patients and the factors modifying them with respect to age and sex.

Materials and Methods: A combined retrospective and prospective observational study was conducted on 200 patients aged between 15-75 years presenting withand admitted with acute intestinal obstruction symptoms. After obtaining ethical committee approval, and getting informed and signed consent from the patients the study was performed and documented.

Results: It was noted that the most common etiology being post-operative adhesion followed by obstructed hernias and other causes were rare. Most common age group was 51-60years. Definite male preponderance was observed.

Conclusion: In the study, it was found that $60 \%$ of them had previous history of abdominal surgeries done for various reasons and post-operative adhesions and peritoneal bands were the cause for obstruction. The next common cause being obstructed hernias followed by other causes like strictures, both small and large bowel volvulus, post TB adhesion, intussusception, intra-abdominal abscesses and tumours were rarely documented in the study group. Among sex predisposition males were significantly more commonly affected than females. Majority of the cases were documented among the 51-60years age group.

Keywords: acute intestinal Obstruction, acute abdomen, post operative adhesions, obstructed hernias.
\end{abstract}

\section{Introduction}

Intestinal obstruction means significant impairment or complete arrest of passage of contents through the intestine. Symptoms include crampy abdominal pain, vomiting, constipation or obstipation. Diagnosis is confirmed both clinically by various imaging modalities. Treatment includes adequate fluid resuscitation which is life-saving followed by nasogastric and bladder decompression which alone may reduce or clear sub-acute obstruction whereas in majority of cases the obstruction progresses and is managed by emergent laparotomy and proceed based on presentation.

\section{Materials and Methods}

Combined Retrospective and Prospective observational study was conducted on 200 patients 


\section{JMSCR Vol||08||Issue||11||Page 12-15||November}

aged between $15-75$ years presenting with acute intestinal obstruction symptoms of which some where acute or chronic presentation with postoperative status. After obtaining ethical committee approval, and getting informed and signed consent from the patients the study was performed and documented. The patients admitted with the obstructive symptoms were studied in terms of: detailed clinical History and examination; Blood investigations: complete hemogram, RFT, serum electrolytes, serum amylase, lipases. Radiological investigations: $\mathrm{x}$-ray Chest PA view, x-ray abdomen (erect and supine views), Ultrasound abdomen and pelvis and CT abdomen. Patients below 15 years of age and those who had not consented were excluded from the study. All patients underwent all the above said investigations and were managed either conservatively or surgically. The findings were documented and analysed.

\section{Study}

Around 200 patients presented to our hospital with symptoms of intestinal obstruction and they were categorised as follows

Table 1: Various causes of patients with acute intestinal obstruction

\begin{tabular}{|l|c|c|c|c|c|c|}
\hline S. No & Obstruction due to & Male & Female & M:F & Total & \% \\
\hline 1 & Adhesions and peritoneal bands & 80 & 40 & $2: 1$ & 120 & 60 \\
\hline 2 & Obstructed hernia & 46 & 14 & $3.2: 1$ & 60 & 30 \\
\hline 3 & Strictures & 6 & 3 & $2: 1$ & 9 & 4.5 \\
\hline 4 & Small bowel volvulus & 4 & 2 & $2: 1$ & 6 & 3 \\
\hline 5 & Intussuseption & 3 & 0 & $3: 0$ & 3 & 1.5 \\
\hline 6 & Intra abdominal abscess & 0 & 1 & $0: 1$ & 1 & 0.5 \\
\hline 7 & Tumours & 1 & 0 & $1: 0$ & 1 & 0.5 \\
\hline
\end{tabular}

Fig -1: Histogram depicting causes of intestinal obstruction

Tumours
Intra abdominal abscess
Intussusception
small bowel volvulus
Strictures
Obstructed hernias




\section{JMSCR Vol||08||Issue||11||Page 12-15||November}

Fig -2: Sex Ratio

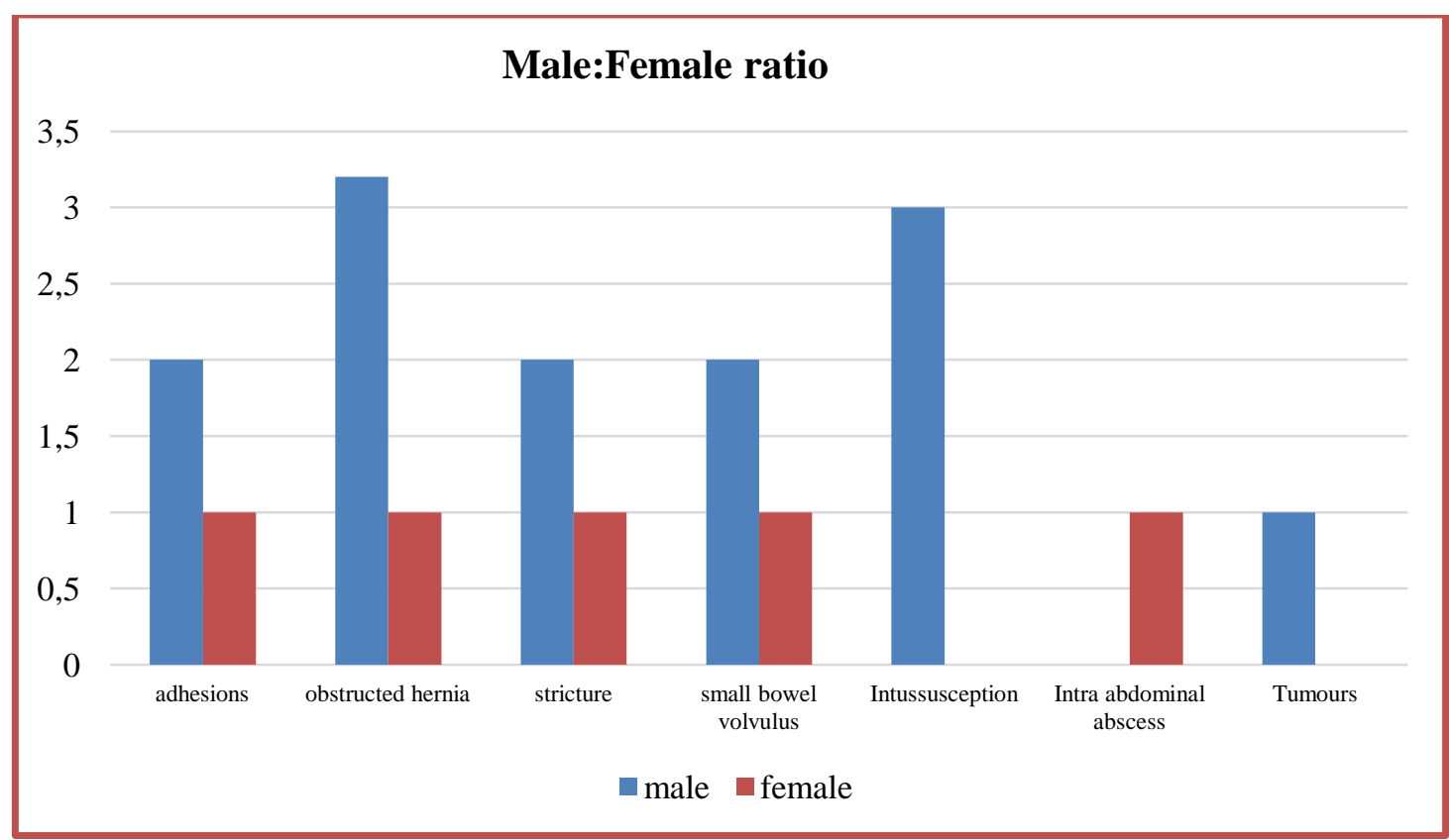

Fig -3: Age wise distribution of cases

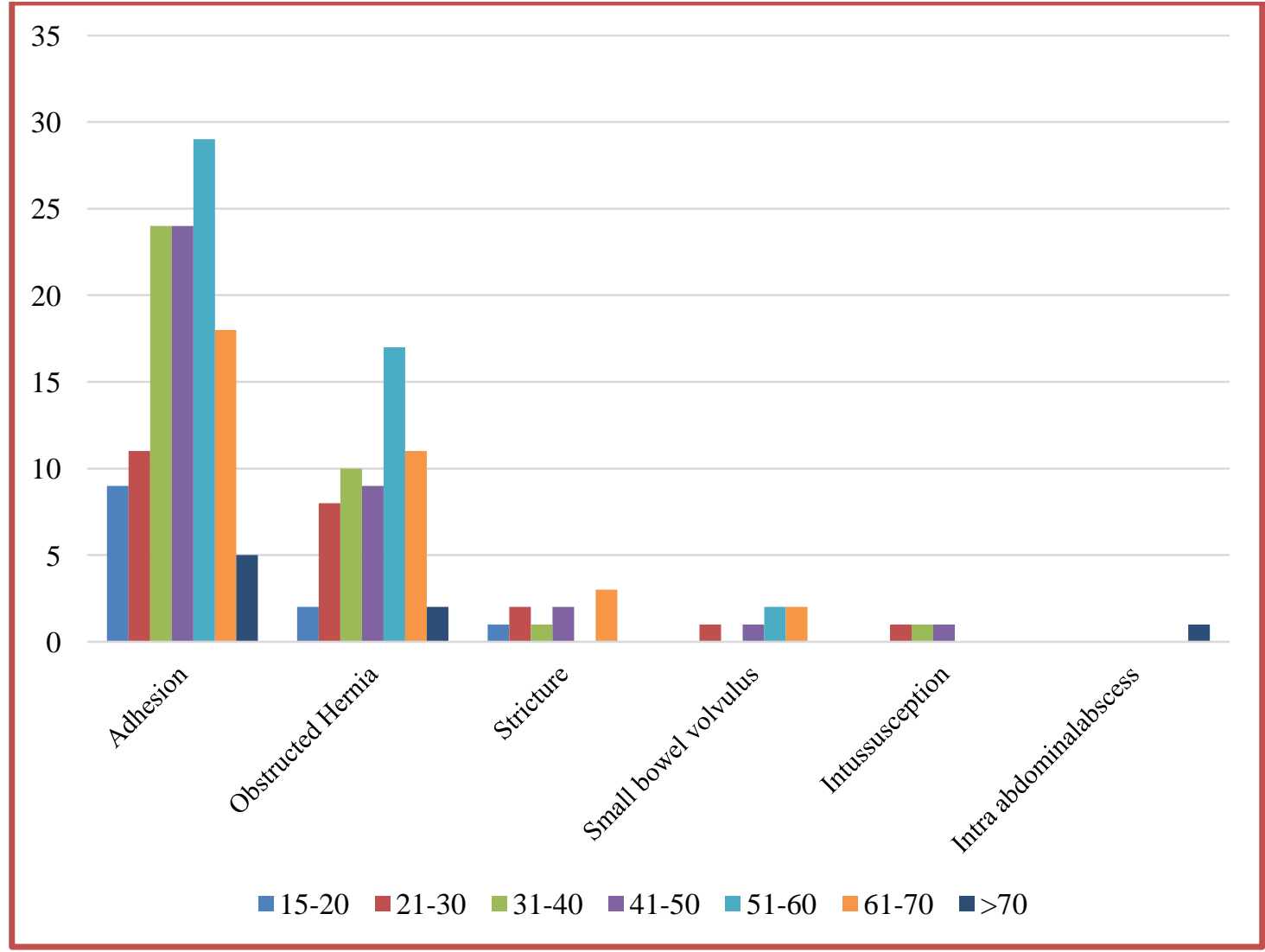

X-axis-age groups

Y-axis-number of cases 
Table: 2 Comparison study of obstruction in India, Africa, West Indies

\begin{tabular}{|c|c|c|c|c|c|c|c|c|}
\hline $\begin{array}{c}\text { Types of } \\
\text { obstruction }\end{array}$ & $\begin{array}{c}\text { Badod Accra } \\
\text { (Ghana) }\end{array}$ & $\begin{array}{c}\text { Gill \& } \\
\text { eggleston } \\
\text { (Punjab) }\end{array}$ & $\begin{array}{c}\text { Cole Ibdam } \\
\text { (Nigeria) }\end{array}$ & $\begin{array}{c}\text { AAC Adam } \\
\text { (kampala, } \\
\text { Uganda) }\end{array}$ & $\begin{array}{c}\text { Local study } \\
\text { (Bulawayo, } \\
\text { Zimbabwe) }\end{array}$ & $\begin{array}{c}\text { Cheadozi } \\
\text { (Nigeria) }\end{array}$ & $\begin{array}{c}\text { Brooks \& } \\
\text { Bufaler } \\
\text { (Jamaica) }\end{array}$ & Our study \\
\hline Adhesion & 10 & 15 & 10 & 4 & 17 & 10 & 23 & 120 \\
\hline Hernia & 77.6 & 27 & 35 & 75 & 36 & 65 & 25 & 60 \\
\hline Intussusception & 4 & 1 & 27 & 4 & 7 & 11.4 & 19 & 3 \\
\hline Malignancy & 0.6 & - & 1 & 1 & - & 0.3 & 5 & 1 \\
\hline Tuberculosis & - & 3 & 0.7 & - & - & - & - & 9 \\
\hline $\begin{array}{c}\text { Volvulus (Large } \\
\text { bowel) }\end{array}$ & 1 & 9 & 3 & 0.4 & 8 & 8 & 0.4 & 0 \\
\hline $\begin{array}{c}\text { Volvulus } \\
\text { (Small bowel) }\end{array}$ & 1 & 16 & 3 & 0.4 & 8 & 8 & 0.4 & 6 \\
\hline $\begin{array}{c}\text { Intra abdominal } \\
\text { abscess }\end{array}$ & - & - & - & - & - & - & - & 1 \\
\hline Total cases & 782 & 147 & 436 & 794 & 172 & 316 & 250 & 200 \\
\hline
\end{tabular}

\section{Results}

- Most common cause of acute intestinal obstruction was post-operative adhesions and bands followed by obstructed hernias.

- Over all males were significantly affected more than females.

- Age wise population of the Range 51-60 years were affected more compared to other age groups in both adhesions and obstructed hernias.

\section{Conclusion}

In the study conducted it was found that the most common cause of acute intestinal obstruction was post-operative adhesions and peritoneal bands followed by obstructed hernias whereas other causes of acute intestinal obstruction like strictures, volvulus (both small and large bowel), intussusception, intra-abdominal abscesses were comparatively rare. With respect to sex preponderance males were affected more commonly than females and age wise 51-60years had highest incidence of $24.17 \%$ and $11.67 \%$ for adhesions and obstructed hernias respectively amongst the study group. Second peak of cases were observed among 31-40 years of age at 20\% and $16.67 \%$ for adhesions and obstructed hernias respectively.
Declaration of Conflict of Interest: There is no conflict of interest

Funding: This research received no specific grant from any funding agency in the public, commercial, or not-for-profit sectors.

\section{References}

1. Acute intestinal Surgery, American Journal of Surgery, AJS 19:172,

2. Adhesive Intestinal obstruction Ann. Surgery

3. British Journal of surgery, BJS

4. Intestinal Obstruction Claude E.Welch

5. Indian Journal of Surgery

6. Gastrointestinal Disease, Sleisenger and Fordtum $5^{\text {th }}$ edition

7. Maingot's Abdominal Operations

8. Bailey and Love short Practice of Surgery, International Students Edition, $27^{\text {th }}$ Edition

9. Sabiston Textbook of Surgery, First South Asia Edition

10. Farquharson's Textbook of Operative surgery, $10^{\text {th }}$ edition

11. Gore \& Levine textbook of gastrointestinal Radiology, $4^{\text {th }}$ edition. 